\title{
Low Serum Thyroxine due to Anti-Thyroxine Antibody
}

\author{
KATSUji IKEKUBO ${ }^{1}$, JUNJi KONISHI ${ }^{1}$, Kотоко NAKAJIMA ${ }^{1}$, \\ KEIGO ENDO ${ }^{1}$, TORU MORI ${ }^{2}$ AND KANJI TORIZUKA ${ }^{1}$ \\ ${ }^{1}$ Department of Radiology, Kyoto University School of Medicine, \\ Kyoto 606 and ${ }^{2}$ Department of Internal Medicine, Kobe \\ Central Municipal Hospital, Kobe 650, Japan
}

\begin{abstract}
Synopsis
In one case of untreated Hashimoto's thyroiditis, the serum thyroxine $\left(\mathrm{T}_{4}\right)$ value, obtained by radioimmunoassay (RIA) employing resin to separate bound and free $\mathrm{T}_{4}$, was significantly lower than that obtained by competitive protein binding analysis (CPBA). The discrepancy was found to be due to the presence of anti-thyroxine autoantibody in the serum. This phenomenon is considered to be of practical importance in interpreting the $T_{4}$ value by RIA in cases with autoimmune thyroid diseases.
\end{abstract}

The binding of serum thyroxine $\left(\mathrm{T}_{4}\right)$ to gammaglobulin has been reported in patients with thyroid cancer (Robbins et al., 1956) and Hashimoto's thyroiditis (Premachandra and Blumentha1, 1967; Ochi et al., 1972). Recently Staeheli et al. (1975) demonstrated the presence of anti- $\mathrm{T}_{4}$ and anti-triiodothyronine $\left(T_{3}\right)$ antibodies in different thyroid conditions by disrupting the antigen-antibody complex, and predicted the possibility of spuriously high or low serum $\mathrm{T}_{4}$ and $\mathrm{T}_{3}$ values by radioimmunoassay (RIA) due to these antibodies.

In fact, one case of euthyroid Graves' disease with ophthalmopathy has been reported to have undetectable $\mathrm{T}_{3}$ by RIA, while large amounts of $T_{3}$ could be detected from an ethanol extract of the serum (Sterling et al., 1973). In addition, a patient with abnormal $\mathrm{T}_{3}$-binding immunoglobulins has also been described ( $\mathrm{Wu}$ and Green, 1976). In this case, using a single-antibody technique, serum $T_{3}$ (RIA) was reported as being indeterminate due to this abnormal

Received October 25, 1977.
$\mathrm{T}_{3}$-binding protein. However, when a double-antibody method was used a high $\mathrm{T}_{3}$ value was obtained.

We have recently studied a patient with Hashimoto's thyroiditis whose serum $\mathbf{T}_{4}$ value measured by a single-antibody RIA was much lower than that measured by competitive protein binding analysis (CPBA). It is suggested that this discrepancy is caused by the presence of the anti- $\mathrm{T}_{4}$ autoantibody in the serum.

\section{Materials and Methods}

The patient was a 59-year-old woman with 30year history of goiter. A diagnosis of Hashimoto's thyroiditis had been established by open biopsy of the thyroid gland ten years previously. Since then she had not taken any drugs. In April, 1975 she was examined again because of further enlargement of the thyroid, and was judged to be euthyroid on the basis of clinical and laboratory findings (mean serum $\mathrm{T}_{4}$ by CPBA, $5.0 \mu \mathrm{g} / 100 \mathrm{ml}$; serum $\mathrm{T}_{3}, 165$ $\mathrm{ng} / 100 \mathrm{ml} ; \mathrm{T}_{3}$ resin uptake, $31.8 \%$; and serum $\mathrm{TSH}$, $2.0 \mu \mathrm{U} / \mathrm{m} l)$. Microscopic examination of the thyroid gland, obtained by needle biopsy at this time, showed degeneration of the follicular epithelium and widespread lymphocytic infiltration. This finding was 
not markedly different from that of the open biopsy specimen obtained ten years previously. The $\mathrm{T}_{4}$ binding capacity of TBG in her serum was $24 \mu \mathrm{g} / 100$ $\mathrm{m} l$. Anti-thyroglobulin antibody (anti-Tg) by the tanned red-cell agglutination test was negative. The serum $\mathrm{T}_{4}$ was measured by the following kits, $\mathrm{T}_{4}$ RIA (Abbott Lab., North Chicago), RIA-Mat $T_{4}$ (Mallinckrodt, Inc., St. Louis), Tetrasorb (Dainabot Co., Tokyo) and Tetra-Tab (Nuclear medical Lab., Inc., Taxas). $\mathrm{T}_{4}$ values by RIA (using $\mathrm{T}_{4}$ RIA and RIA-Mat $\mathrm{T}_{4}$ kits) in sera from normal subjects and from patients with various thyroid diseases were found to be in good correlation with those obtained by a CPBA kit, Tetrasorb. Values obtained by two CPBA kits, Tetrasorb and Tetra-Tab, also showed close correlation.

The 19S and $7 \mathrm{~S}$ protein fractions of the serum were obtained by gel filtration through a Sephadex G-200 column $(1.5 \times 90 \mathrm{~cm})$ in phosphate buffered saline (PBS) $0.02 \mathrm{M}, \mathrm{pH}$ 7.6. The IgG fraction of the serum was prepared by a DEAE cellulose column chromatography with a $0.01 \mathrm{M}$ phosphate buffer, $\mathrm{pH}$ 7.6. ${ }^{125} \mathrm{I}$ labelled $\mathrm{T}_{4}\left({ }^{125} \mathbf{I}_{-} \mathrm{T}_{4}\right)$ was obtained from Dainabot Laboratories, Tokyo; the specific activity was $620 \mu \mathrm{Ci} / \mu \mathrm{g}$.

The binding of ${ }^{125} \mathrm{I}_{-} \mathrm{T}_{4}$ to the serum or fractions of the serum was studied by the following methods:

1) Using RIA kit systems

The binding of ${ }^{125} \mathrm{I}_{-} \mathrm{T}_{4}$ to the serum was studitd by using two kinds of RIA kits without the addition of the provided anti- $T_{4}$ serum. After incubation of the serum with ${ }^{125} \mathrm{I}-\mathrm{T}_{4}$, free ${ }^{125} \mathrm{I}-\mathrm{T}_{4}$ was separated from the bound by the provided anionic exchange resin.

2) Polyethylene glycol (PEG) method

Fifty $\mu l$ of the serum were incubated with ${ }^{125} \mathrm{I}_{-} \mathrm{T}_{4}$ $(30,000 \mathrm{cpm})$ in $50 \mu l$ of $0.075 \mathrm{M}$ barbital buffer, $\mathrm{pH} 8.6$ with $1,200 \mu \mathrm{g} / \mathrm{ml}$ of 8 -anilino-1-naphthalene-sulfonic acid (ANS), for $20 \mathrm{hr}$ at $4^{\circ} \mathrm{C}$. In the cases of $19 \mathrm{~S}$, 7S and IgG fractions (about $500 \mu \mathrm{g}$ each), and anti- $\mathrm{T}_{4}$ rabbit serum of the RIA-Mat $\mathrm{T}_{4}$ kit, $50 \mu \mathrm{l}$ of each were incubated in the same manner for $20 \mathrm{hr}$ at $4^{\circ} \mathrm{C}$ without the addition of ANS. At the end of the incubation period, normal human $\gamma$-globulin was added to the same concentration as IgG. An aqueous solution of PEG (Carbowax 6,000) was added to makea final concentration of $12.5 \%$. The tubes were then centrifuged at $3,000 \mathrm{rpm}$ for $20 \mathrm{~min}$ at $4^{\circ} \mathrm{C}$. The supernate was decanted and the radioactivity of the precipitate was counted.

3) Double antibody method

Five $\mu l$ of the serum were incubated with ${ }^{125} \mathrm{I}_{-}-\mathrm{T}_{4}$ in a $0.075 \mathrm{M}$ barbital buffer, $\mathrm{pH} 8.6$ containing 600 $\mu \mathrm{g} / \mathrm{ml}$ of ANS, for $20 \mathrm{hr}$ at $4^{\circ} \mathrm{C}$. Purified IgG fraction (about $10-50 \mu \mathrm{g}$ ) was incubated in the same manner without ANS. After the addition of an excess of anti-human IgG goat serum, the mixture $(200 \mu l)$ was incubated for another $20 \mathrm{hr}$ in the same condition and centrifuged at $10,000 \times g$ for $10 \mathrm{~min}$.
4) Column chromatography

(a) The patient's serum, a control serum and the anti- $\mathrm{T}_{4}$ rabbit serum (from RIA-Mat $\mathrm{T}_{4}$ ) were incubated with ${ }^{125} \mathrm{I}_{-} \mathrm{T}_{4}$ under the presence of ANS $(600 \mu \mathrm{g} / \mathrm{m} l)$ at room temperature for one hr. Each of the mixtures was then applied to a Sephadex G-200 column $(1.0 \times 30 \mathrm{~cm})$ and the column was eluted with barbital buffer, $0.075 \mathrm{M}, \mathrm{pH} 8.6$ containing the same concentration of ANS. Fifteen drop alliquots were collected and radioactivity was counted.

(b) The serum was incubated with ${ }^{125} \mathrm{I}-\mathrm{T}_{4}$ after thermal inactivation $\left(60^{\circ} \mathrm{C}, 2 \mathrm{hr}\right)$ of TBG (Sterling and Milch, 1974). The incubation mixture was applied to a Sehadex G-200 column $(1.0 \times 90 \mathrm{~cm})$, and was eluted with PBS $0.02 \mathrm{M}, \mathrm{pH}$ 7.6. Three $\mathrm{m} l$ fractions were collected and both radioactivity and optical density at $280 \mathrm{~nm}$ were measured.

\section{Results}

The serum $T_{4}$ values measured by RIA and $C P B A$.

The mean serum $\mathrm{T}_{4}$ measured twice in duplicate by $\mathrm{T}_{4}$ RIA, RIA-Mat $\mathrm{T}_{4}$, Tetrasorb and Tetra-Tab kits were $1.70 \pm 0.90$ (SD), $2.9 \pm 0.37$ (SD), $5.4 \pm 0.34(\mathrm{SD})$ and $4.6 \pm 0.26(\mathrm{SD}) \mu \mathrm{g} / 100 \mathrm{~m} l$, respectively. The mean recoveries of 0.5 to $10 \mathrm{ng}$ nonradioactive $\mathrm{T}_{4}$ added to the patient's serum, evaluated by $\mathrm{T}_{4}$ RIA and RIA-Mat $\mathrm{T}_{4}$ kits, were $74.2 \%$ and $71.2 \%$, respectively. While the mean recoveries of $\mathrm{T}_{4}$ obtained in three control sera were 110 and $108 \%$, respectively.

Binding of ${ }^{125} I-T_{4}$ to the patient's serum. The significant binding of ${ }^{125} \mathrm{I}-\mathrm{T}_{4}$ to the patient's serum was observed by using the $\mathrm{T}_{4}$ RIA and RIA-Mat $\mathrm{T}_{4}$ systems without anti- $\mathrm{T}_{4}$ serum (Table 1).

Fig. 1 shows the result of Sephadex G-200 column chromatography of ${ }^{125} \mathrm{I}_{-} \mathrm{T}_{4}$ preincubated with the test sera or with the rabbit anti- $\mathrm{T}_{4}$ antibody under the presence of ANS. An early radioactive peak was observed by using the patient's serum, as in the case of the anti- $T_{4}$ antibody, whereas such radioactivity was not detected by using a control serum. 
Fig. 2 compares the elution patterns from a Sephadex G-200 column of ${ }^{125} \mathrm{I}_{-} \mathrm{T}_{4}$ added to heat-treated patient's and normal control sera. Only with the patient's serum was an early radioactive peak observed in the area where the $7 \mathrm{~S}$ protein fraction was eluted. The binding of ${ }^{125} \mathrm{I}_{-} \mathrm{T}_{4}$ to the $7 \mathrm{~S}$ and IgG fractions determined by the PEG method were $34.0 \%$ and $51.0 \%$, respectively, whereas binding to the $19 \mathrm{~S}$ fraction was negligible (Table 2). By using the double antibody method, the binding of ${ }^{125} \mathrm{I}_{-} \mathrm{T}_{4}$ to the patient's serum and its $\mathrm{IgG}$ fraction were 15.4 and $9.0 \%$, respectively, while

Table 1. Binding of ${ }^{125} \mathrm{I}_{-} \mathrm{T}_{4}$ to the serum detected by using the $\mathrm{T}_{4}$ RIA and RIA-Mat $\mathrm{T}_{4}$ systems without anti- $\mathrm{T}_{4}$ serum. ${ }^{125} \mathrm{I}_{-} \mathrm{T}_{4}$ binding to the anti- $\mathrm{T}_{4}$ rabbit serum of each kit was shown for comparison.

\begin{tabular}{lcc}
\hline & \multicolumn{2}{c}{$\%$ bound with } \\
\cline { 2 - 3 } & \multicolumn{1}{c}{$\mathrm{T}_{4}$ RIA } & RIA-Mat $\mathrm{T}_{4}$ \\
\hline $\begin{array}{l}\mathrm{Pt} . \\
(\mathrm{n}=2)\end{array}$ & $31.7 \pm 1.70(\mathrm{SD}) \%$ & $16.8 \pm 1.27(\mathrm{SD}) \%$ \\
$\begin{array}{l}\text { Control } \\
(\mathrm{n}=5)\end{array}$ & $17.4 \pm 1.82(\mathrm{SD}) \%$ & $6.8 \pm 0.34(\mathrm{SD}) \%$ \\
$\begin{array}{l}\text { Anti-T } \\
\text { rabbit serum } \\
(\mathrm{n}=5)\end{array}$ & $80.6 \pm 1.14(\mathrm{SD}) \%$ & $60.6 \pm 3.09(\mathrm{SD}) \%$ \\
\hline
\end{tabular}

Table 2. Binding of ${ }^{125} \mathbf{I}-\mathrm{T}_{4}$ to the serum and its fractions detected by precipitation at $12.5 \%$ PEG.

\begin{tabular}{lrrrr}
\hline \hline & Serum & $19 \mathrm{~S}$ & \multicolumn{1}{c}{$7 \mathrm{~S}$} & \multicolumn{1}{c}{ IgG } \\
\hline Pt. & $30.1 \%$ & $0.5 \%$ & $34.0 \%$ & $51.0 \%$ \\
Control & $8.5 \%$ & $0.2 \%$ & $6.2 \%$ & $6.0 \%$ \\
\hline
\end{tabular}

Table 3. Binding of ${ }^{125} \mathrm{I}-\mathrm{T}_{4}$ to the serum and its IgG fraction detected by using double antibody method.

\begin{tabular}{lcc}
\hline & \multicolumn{2}{c}{$\begin{array}{c}125 \mathrm{I}-\mathrm{T}_{4} \text { precipitated by } \\
\text { anti-IgG }\end{array}$} \\
\cline { 2 - 3 } & Serum & IgG \\
\hline Pt. & $15.4 \%$ & $9.0 \%$ \\
Control & $1.8 \%$ & $0.5 \%$ \\
\hline
\end{tabular}

In the case of the serum, ANS was added in a final concentration of $600 \mu \mathrm{g} / \mathrm{ml}$. the binding to a control serum and its IgG fraction were $1.8 \%$ and $0.5 \%$ (Table 3 ). However, when the untreated patient's serum was incubated with ${ }^{125} \mathrm{I}_{-} \mathrm{T}_{4}$ without addition of ANS, no significant radioactivity was observed in the $\gamma$-globulin or $7 \mathrm{~S}$ region on paper electrophoresis or Sephadex G-200 gel filtration.

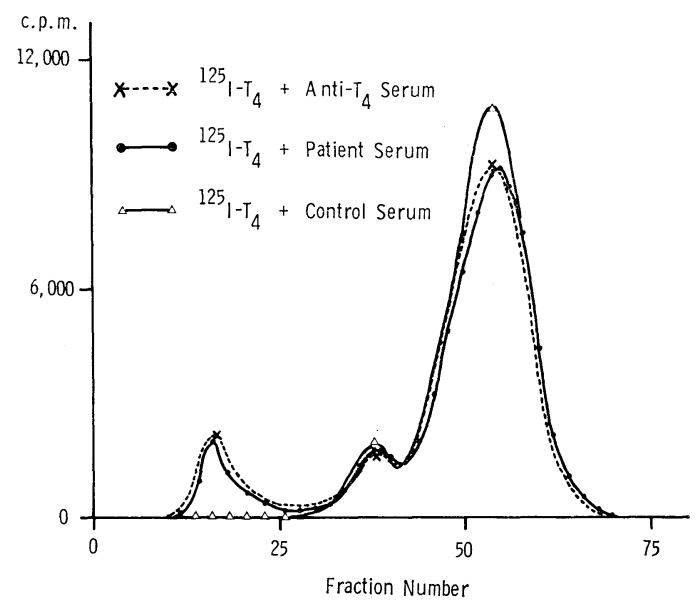

Fig. 1. Sephadex G-200 column chromatography of ${ }^{125} \mathrm{I}_{-} \mathrm{T}_{4}$ preincubated with the sera from a patient and a control, and the rabbit anti- $\mathrm{T}_{4}$ serum in the presence of ANS.

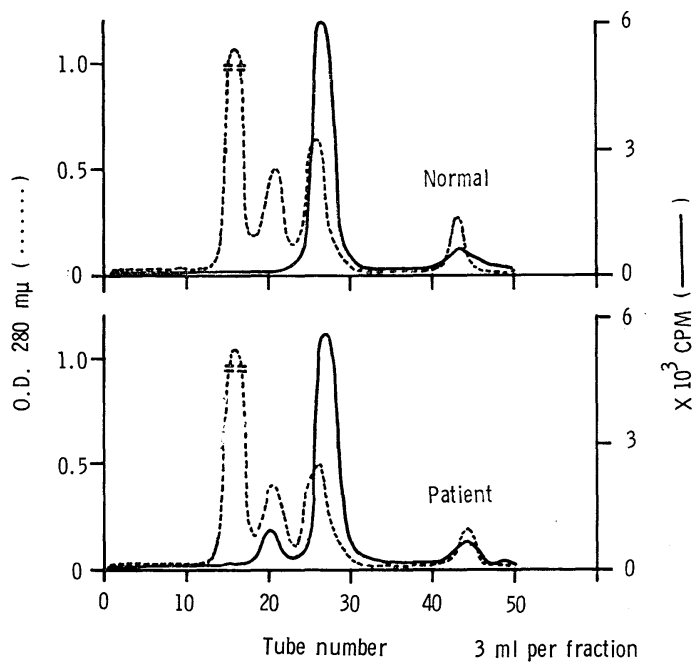

Fig. 2. Sephadex G-200 column chromatography of ${ }^{125} \mathrm{I}_{-} \mathrm{T}_{4}$ preincubated with the heat-treated serum; protein peaks (OD 280) are shown as dotted lines and radioactivity as solid lines. 
Specificity of the $T_{4}$ binding.

Fig. 3 shows the dose-dependent displacement of binding of ${ }^{125} \mathrm{I}_{-} \mathrm{T}_{4}$ to the patient's IgG by the addition of unlabeled $\mathrm{T}_{4}$. The assay was performed by PEG method. The cross reaction with $\mathrm{T}_{3}$ was approximately $8.3 \%$. MIT and DIT did not displace the labeled $\mathrm{T}_{4}$ when tested in amounts varying from 0.1 to $100 \mathrm{ng}$ per assay. No binding to the serum of other radioactive peptide hormones such as TSH, $\mathrm{HGH}$ or insulin could be detected.

Association constant and binding capacity for $T_{4}$ of the patient's IgG and the anti- $T_{4}$ rabbit serum of RIA-Mat $T_{4}$.

The Scatchard plots (Scatchard, 1949) of the $T_{4}$ binding to the patient's IgG and the anti- $\mathrm{T}_{4}$ serum of the RIA-Mat $\mathrm{T}_{4}$ are shown in Fig. 4.

The association constants for $\mathrm{T}_{4}$ were calculated to be $1.9 \times 10^{8} \mathrm{l} / \mathrm{mol}$ and $1.2 \times$ $10^{9} \mathrm{l} / \mathrm{mol}$, and the binding capacities were $0.8 \mu \mathrm{g} / 100 \mathrm{~m} l$ serum and $0.3 \mu \mathrm{g} / 100 \mathrm{~m} l$ serum, respectively. As $10 \mu \mathrm{l}$ of serum sample and $100 \mu l$ of anti-T $\mathrm{T}_{4}$ serum were used in RIA-Mat $\mathrm{T}_{4}$, the binding capacities of the patient's $\operatorname{IgG}$ and the anti- $\mathrm{T}_{4}$ serum for $\mathrm{T}_{4}$ in this system were $0.08 \mathrm{ng}$ and $0.3 \mathrm{ng}$, respectively.

\section{Discussion}

By using single antibody RIA systems, significantly lower serum $\mathrm{T}_{4}$ values than those by CPBA were obtained in the present case with Hashimoto's thyroiditis. Possible under-estimation of the serum $\mathrm{T}_{4}$ by RIA was suspected because the patient was clinically euthyroid and no elevation of serum TSH was present. In experiments where nonradioactive $T_{4}$ was added to the patient's serum, the recovery of $\mathrm{T}_{4}$ determined by RIA was significanly low. The binding of ${ }^{125} \mathrm{I}-\mathrm{T}_{4}$ to the patients serum was confirmed by several methods. And the

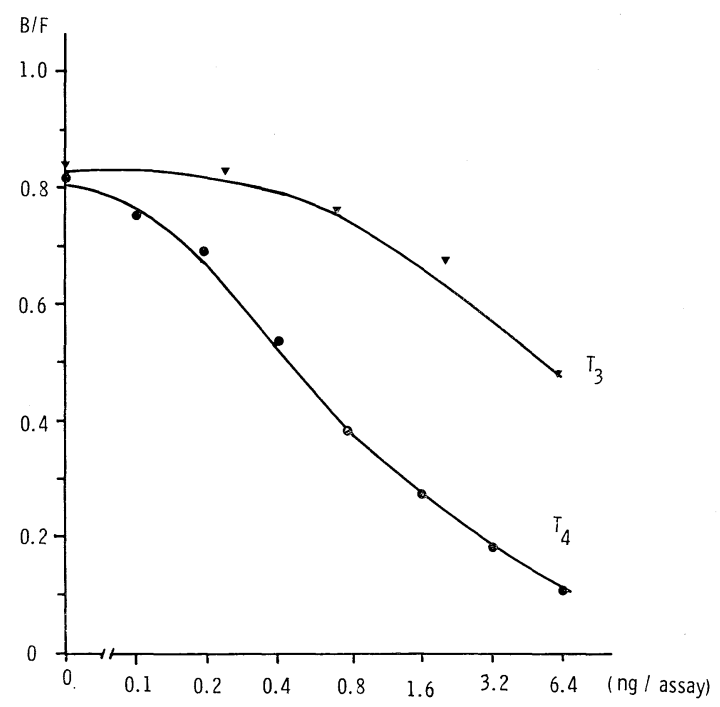

Fig. 3. Inhibition of the binding of ${ }^{125} \mathrm{I}-\mathrm{T}_{4}$ by $\mathrm{T}_{4}$ or $\mathrm{T}_{3}$.
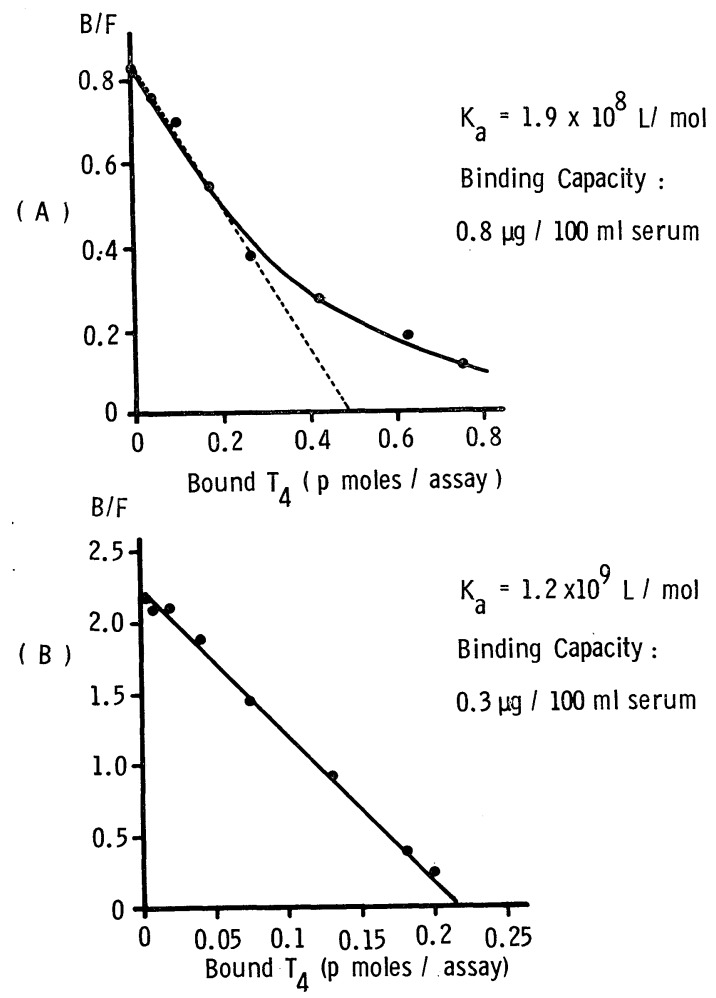

Fig. 4. Scatchard plot of $\mathrm{T}_{4}$ binding to ; (A) Patient's IgG (B) Anti- $T_{4}$ rabbit serum of RIA-Mat $T_{4}$. 
binding activity was present in the IgG fraction of the serum. All these data should be reasonably understood assuming a concept that the presence of the $\mathrm{T}_{4}$ binding IgG could produce spuriously low $T_{4}$ value in the RIA system used. In fact the methods employed are based on absorption of free $T_{4}$ by resin. Therefore, the presence of the anti- $T_{4}$ antibody increased the bound fraction, resulting in a decrease of the $T_{4}$ values obtained.

Recently Wu and Green (1976) reported a case with $\mathrm{T}_{3}$-binding immunoglobulin, which evoked artefactually high or low $T_{3}$ measurements depending on the method employed.

The association constant of the patient's IgG against $\mathrm{T}_{4}$ was $1.9 \times 10^{8} \mathrm{l} / \mathrm{mol}$, and this was somewhat lower than that of the anti- $\mathrm{T}_{4}$ rabbit serum of RIA-Mat $\mathrm{T}_{4}, 1.2 \times$ $10^{9} \mathrm{l} / \mathrm{mol}$. Its binding capacity was about $1 / 4$ of that of the latter under the assay condition. This limited affinity and capacity of this IgG may explain the reason why we could not see the binding of ${ }^{125} \mathrm{I}-$ $\mathrm{T}_{4}$ to the $\gamma$-globulin or IgG without the presence of the binding inhibitor to TBG.

Therefore, the presence of this anti- $\mathrm{T}_{4}$ antibody in the serum was considered to have quite a limited effect on the $T_{4}$ distribution in the serum. However, the fact that even such a low affinity immunoglobulin could significantly affect $T_{4}$ value in RIA was considered to be of practical importance.

As the binding of $T_{4}$ to the patient's IgG was demonstrated to be specific, this $\mathrm{T}_{4}$-binding $\operatorname{IgG}$ was considered to be an anti- $T_{4}$ autoantibody. Although the binding of $T_{3}$ to the IgG was also observed, the binding affinity was much lower than that with $\mathrm{T}_{4}$ and this binding was considered to be the cross-reaction of $T_{3}$ with the anti$\mathrm{T}_{4}$ antibody.

Although the possibility that thyroid medication might evoke an antibody formation against the thyroid hormone was suggested by Staeheli et al. (1975), the patients in the present study had received no treatment for 10 years. Her serum anti-Tg, which had been positive 10 years ago was negative at the time of the present study. Staeheli et al. (1975) have also reported cases with anti- $\mathrm{T}_{4}$ antibodies without anti-Tg. Further accumulation of case studies is required for the understanding of these antibodies.

The existence of such a case should be kept in mind to avoid possible erroneous clinical interpretation of the $\mathrm{T}_{4}$ value by RIA. As was shown by $\mathrm{Wu}$ and Green (1976) for $T_{3}$, if the double antibody method is used for the assay, the value would be high in this case. $\mathrm{T}_{4}$ assay after extraction should be performed when the data on unextracted serum are discordant with the clinical state, especially in cases with autoimmune thyroid diseases.

\section{Acknowledgements}

We are grateful to Dr. Shunyo Yakura for his help in studying the case. We wish to thank Miss Chisako Furumatsu for the preparation of the manuscript.

\section{References}

Ochi, Y., K. Shiomi, T. Hachiya, M. Yoshimura and T. Miyazaki (1972). J. Clin. Endocrinol. Metab. $35,743$.

Premachandra, B. N. and H. T. Blumenthal (1967). ibid. 27, 931 .

Robbins, J., J. E. Rall and R. W. Rawson (1956). ibid. 16, 573.

Scatchard, G. (1949). Ann. N. Y. Acad. Sci. 51, 660. Staeheli V., M. B. Vallotton and A. Burger [(1975). J. Clin. Endocrinol. Metab. 41, 669.

Sterling, K., P. O. Milch, D. A. Holub and A. Burger Program 49th Ann. Meet. Amer. Thyroid Assoc., p. T Il (Abstract), (1973).

Sterling, K. and P. O. Milch (1974). J. Clin. Endocrinol. Metab. 38, 866.

Wu, S. Y. and W. L. Green (1976). ibid. 42, 642. 